\title{
Structural changes in the $\mathrm{C}$-terminus of $\mathrm{Ca}^{2+}$-bound rat $\operatorname{S100B}(\beta \beta)$ upon binding to a peptide derived from the $\mathrm{C}$-terminal regulatory domain of p53
}

\author{
RICHARD R. RUSTANDI, DONNA M. BALDISSERI, ALEXANDER C. DROHAT, \\ AND DAVID J. WEBER \\ Department of Biochemistry and Molecular Biology, University of Maryland School of Medicine, Baltimore, Maryland 21201
}

(Received December 1, 1998; ACCEPTED February 28, 1999)

\begin{abstract}
$\mathrm{S} 100 \mathrm{~B}(\beta \beta)$ is a dimeric $\mathrm{Ca}^{2+}$-binding protein that interacts with $\mathrm{p} 53$, inhibits its phosphorylation by protein kinase $\mathrm{C}$ $(\mathrm{PKC})$ and promotes disassembly of the $\mathrm{p} 53$ tetramer. Likewise, a 22 residue peptide derived from the $\mathrm{C}$-terminal regulatory domain of $\mathrm{p} 53$ has been shown to interact with $\mathrm{S} 100 \mathrm{~B}(\beta \beta)$ in a $\mathrm{Ca}^{2+}$-dependent manner and inhibits its phosphorylation by PKC. Hence, structural studies of $\mathrm{Ca}^{2+}$-loaded $\mathrm{S} 100 \mathrm{~B}(\beta \beta)$ bound to the $\mathrm{p} 53$ peptide were initiated to characterize this interaction. Analysis of nuclear Overhauser effect (NOE) correlations, amide proton exchange rates, ${ }^{3} J_{\mathrm{NH}-\mathrm{H} \alpha}$ coupling constants, and chemical shift index data show that, like apo- and $\mathrm{Ca}^{2+}$-bound $\mathrm{S} 100 \mathrm{~B}(\beta \beta), \mathrm{S} 100 \mathrm{~B}$ remains a dimer in the p53 peptide complex, and each subunit has four helices (helix 1, Glu2-Arg20; helix 2, Lys29-Asn38; helix 3, Gln50-Asp61; helix 4, Phe70-Phe87), four loops (loop 1, Glu21-His25; loop 2, Glu39-Glu49; loop 3, Glu62-Gly66; loop 4, Phe88-Glu91), and two $\beta$-strands ( $\beta$-strand 1, Lys26-Lys28; $\beta$-strand 2, Glu67-Asp69), which forms a short antiparallel $\beta$-sheet. However, in the presence of the p53 peptide helix 4 is longer by five residues than in apo- or $\mathrm{Ca}^{2+}$-bound $\mathrm{S} 100 \mathrm{~B}(\beta \beta)$. Furthermore, the amide proton exchange rates in helix 3 (K55, V56, E58, T59, L60, D61) are significantly slower than those of $\mathrm{Ca}^{2+}$-bound $\mathrm{S} 100 \mathrm{~B}(\beta \beta)$. Together, these observations plus intermolecular NOE correlations between the $\mathrm{p} 53$ peptide and $\operatorname{S100B}(\beta \beta)$ support the notion that the p53 peptide binds in a region of $\operatorname{S100B}(\beta \beta)$, which includes residues in helix 2, helix 3, loop 2, and the C-terminal loop, and that binding of the p53 peptide interacts with and induces the extension of helix 4.
\end{abstract}

Keywords: calcium-binding protein; NMR; p53; S100B; S100 protein

The reduced homodimeric protein, $\operatorname{S} 100 \mathrm{~B}(\beta \beta)$, is one of the best characterized proteins of the S100 family. The solution structure of apo- $\operatorname{S100B}(\beta \beta)$ shows that two subunits associate tightly $\left(K_{d}<\right.$ $500 \mathrm{pM})$ (Drohat et al., 1997) through extensive hydrophobic interactions to form a compact dimer with a highly charged surface (Amburgey et al., 1995; Drohat et al., 1996; Kilby et al., 1996; Drohat et al., 1999). Recently, the solution and crystal structures of

Reprint requests to: David J. Weber, University of Maryland School of Medicine, Department of Biochemistry and Molecular Biology, 108 North Greene Street, Baltimore, Maryland 21201; e-mail: dweber@umaryland.edu.

Abbreviations: 1D, 2D, and 3D, one-, two-, and three-dimensional; PKC, protein kinase C; DTT, dithiothreitol; $\mathrm{p} 53$, tumor suppressor protein; $\mathrm{S} 100 \beta$, a subunit of dimeric $\mathrm{S} 100 \mathrm{~B}(\beta \beta) ; \mathrm{S} 100 \mathrm{~B}(\beta \beta)$, dimeric $\mathrm{S} 100 \mathrm{~B}$ with noncovalent interaction at the dimer interface; TSP, sodium 3-(trimethylsilyl) propionate-2,2,3,3- $d_{4}$; TFE, trifluoroethanol; CapZ, actin capping protein; NOE, nuclear Overhauser effect; NOESY, NOE spectroscopy; TOCSY, total correlation spectroscopy; EDTA, ethylenediaminetetraacetic acid; HMQC, heteronuclear multiple quantum coherence; HPLC, highperformance liquid chromatography; HSQC, heteronuclear single quantum coherence.
$\mathrm{Ca}^{2+}$-bound $\operatorname{S100B}(\beta \beta)$ were also solved (Drohat et al., 1998; Matsumura et al., 1998; Smith \& Shaw, 1998), and a comparison of these structures to that of the apo- $\operatorname{S100B}(\beta \beta)$ show that a large change in the position of helix 3 occurs in the $\mathrm{C}$-terminal normal EF-hand for each $\mathrm{S} 100 \beta$ subunit. However, in the N-terminal pseudo EF-hand (which consists of 14 amino acids rather than 12), no conformational change is observed probably because helix 1 remains tightly packed in the dimer interface even upon the addition of $\mathrm{Ca}^{2+}$. The two EF-hand domains of $\mathrm{S} 100 \mathrm{~B}(\beta \beta)$ are connected by a loop (loop 2 ) that is often referred to as the "hinge" region, and a comparison of the amino acid sequences of the S100 family reveals that the hinge and the C-terminal loop are the least conserved among the S100 family proteins. These differences in sequence were the first indication that the "hinge" and the C-terminal loop are important for specific interactions between S100 proteins and their respective targets (Kligman \& Hilt, 1988).

Additional indication that the $\mathrm{C}$-terminal loop and the hinge region are important for target protein binding was illustrated in a study of the interaction between $\operatorname{S100B}(\beta \beta)$ and a peptide corresponding to residues $367-388$ of the C-terminus of human p53 
(Rustandi et al., 1998b). This binding inhibits the PKC-dependent phosphorylation of the p53 peptide (Wilder et al., 1998) and increases the $\mathrm{Ca}^{2+}$-binding affinity to $\operatorname{S100B}(\beta \beta)$ in the C-terminal EF-hand. Furthermore, changes in ${ }^{1} \mathrm{H}$ and ${ }^{15} \mathrm{~N}$ chemical shifts upon p53 peptide binding indicate that the hinge region, the C-terminal loop, and helix 3 likely comprise the p53 peptide binding site on $\operatorname{S100B}(\beta \beta)$ (Rustandi et al., 1998b). In this study, we report that the dimer interface and the two helix-loop-helix $\mathrm{Ca}^{2+}$. binding sites of $\operatorname{S100B}(\beta \beta)$ remain intact upon $\mathrm{p} 53$ peptide binding; however, an extension of helix 4 and significant changes in exchange rates for residues in helix 3 were observed. Together these results show that structural changes in the $\mathrm{C}$-terminus of $\mathrm{Ca}^{2+}$-bound $\mathrm{S} 100 \mathrm{~B}(\beta \beta)$ occur upon target protein binding. A preliminary abstract of this work has been published (Rustandi et al., 1998a).

\section{Results and discussion}

\section{Resonance assignments}

The preliminary backbone chemical shift assignments of $\mathrm{Ca}^{2+}$ loaded $\mathrm{S} 100 \mathrm{~B}(\beta \beta)$ bound to the $\mathrm{p} 53$ peptide reported previously (Rustandi et al., 1998b) were confirmed, and the remaining side chain and aromatic chemical shift assignments were extended to completion $(>99 \%)$ by analyzing data from 2D NOESY, 2D TOCSY, 3D ${ }^{15} \mathrm{~N}$-edited HOHAHA-HSQC, 3D HCCH-TOCSY, $3 \mathrm{D}{ }^{15} \mathrm{~N}$-edited NOESY-HSQC, 3D ${ }^{15} \mathrm{~N},{ }^{15} \mathrm{~N}$-edited HMQCNOESY-HSQC, 3D CBCA $(\mathrm{CO}) \mathrm{NH}$, 3D HNCACB, 3D HNHA, $4 \mathrm{D}{ }^{13} \mathrm{C},{ }^{15} \mathrm{~N}$-edited NOESY-HSQC, and $4 \mathrm{D}{ }^{13} \mathrm{C},{ }^{13} \mathrm{C}$-edited NOESYHMQC NMR experiments. Standard methods were used in the assignment procedure, which relied primarily on scalar connectivities, with the exception being for assignments of aromatic ring protons $(\delta, \epsilon, \zeta)$, which were determined using NOE correlations to numerous assigned resonances (Wuthrich, 1986). The complete listing of the chemical shift assignments (>99\%) of $\mathrm{Ca}^{2+}$-loaded $\mathrm{S} 100 \mathrm{~B}(\beta \beta)$ bound to the $\mathrm{p} 53$ peptide are in supplementary material (Table 1S). ${ }^{1}$

\section{NOE assignments}

Short-range $\mathrm{H}^{\mathrm{N}} \mathrm{H}^{\mathrm{N}}(i, i+1), \mathrm{H}^{\alpha} \mathrm{H}^{\mathrm{N}}(i, i+1), \mathrm{H}^{\beta} \mathrm{H}^{\mathrm{N}}(i, i+1)$, and medium-range $\mathrm{H}^{\mathrm{N}} \mathrm{H}^{\mathrm{N}}(i, i+2), \mathrm{H}^{\alpha} \mathrm{H}^{\mathrm{N}}(i, i+2), \mathrm{H}^{\alpha} \mathrm{H}^{\mathrm{N}}(i, i+3)$, $\mathrm{H}^{\alpha} \mathrm{H}^{\mathrm{N}}(i, i+4), \mathrm{H}^{\alpha} \mathrm{H}^{\beta}(i, i+3)$ NOE correlations were assigned using the $3 \mathrm{D}{ }^{15} \mathrm{~N}$-edited NOESY-HSQC and $3 \mathrm{D}{ }^{13} \mathrm{C}$-edited HMQCNOESY experiments. It was also necessary to collect $3 \mathrm{D}{ }^{15} \mathrm{~N},{ }^{15} \mathrm{~N}$ edited HMQC-NOESY-HSQC, 4D ${ }^{13} \mathrm{C},{ }^{15} \mathrm{~N}$-edited NOESY-HSQC, and $4 \mathrm{D}{ }^{13} \mathrm{C},{ }^{13} \mathrm{C}$-edited NOESY-HMQC NMR data to resolve ambiguities in the assignment of $\mathrm{NOE}$ correlations in $\operatorname{S100B}(\beta \beta)$ bound to the p53 peptide.

Figures 1 and 2 show strips of the ${ }^{15} \mathrm{~N}$-edited NOESYHSQC and ${ }^{15} \mathrm{~N},{ }^{15} \mathrm{~N}$-edited HMQC-NOESY-HSQC spectra, respectively, illustrating residues in helix 4 (F70-F87). Standard methods were used to identify helical conformation such as strong $\mathrm{H}^{\mathrm{N}} \mathrm{H}^{\mathrm{N}}(i, i+1)$, weak $\mathrm{H}^{\alpha} \mathrm{H}^{\mathrm{N}}(i, i+1)$, together with $\mathrm{H}^{\alpha} \mathrm{H}^{\mathrm{N}}(i, i+2), \mathrm{H}^{\alpha} \mathrm{H}^{\mathrm{N}}(i, i+3), \mathrm{H}^{\alpha} \mathrm{H}^{\mathrm{N}}(i, i+4)$, and $\mathrm{H}^{\alpha} \mathrm{H}^{\beta}(i, i+3)$ NOE correlations and small ${ }^{3} J_{\mathrm{NH}-\mathrm{H} \alpha}$ coupling constants typical of

\footnotetext{
${ }^{1}$ The additional side-chain and aromatic chemical shift values were deposited into the BioMagResBank chemical shift database for $\mathrm{Ca}^{2+}$. loaded $\operatorname{S} 100 \mathrm{~B}(\beta \beta)$ bound to the $\mathrm{p} 53$ peptide (accession number 4099).
}

helices (Fig. 4) (Wuthrich, 1986). The significant chemical shift degeneracy observed in helical proteins such as $\operatorname{S100B}(\beta \beta)$ made the NOE assignments with $3 \mathrm{D}$ data alone a difficult process. For example, $\mathrm{A} 83 \mathrm{H}^{\alpha}$ directly overlaps with $\mathrm{M} 79 \mathrm{H}^{\alpha}$, and hence, an $\mathrm{H}^{\alpha} \mathrm{H}^{\mathrm{N}}(i, i+4)$ NOE correlation remains ambiguous in the 3D ${ }^{15} \mathrm{~N}$-edited NOESY-HSQC spectrum. This degeneracy was resolved in the $4 \mathrm{D}{ }^{13} \mathrm{C},{ }^{15} \mathrm{~N}$-edited NOESY-HSQC spectrum (Fig. 3) and demonstrates unequivocally the $\mathrm{H}^{\alpha} \mathrm{H}^{\mathrm{N}}(i, i+4)$ NOE correlation for M79 and A83. Similarly, for residue A75 in the 3D ${ }^{15} \mathrm{~N}-$ edited NOESY-HSQC experiments, resonance $\mathrm{A} 75 \mathrm{H}^{\alpha}$ overlaps with $\mathrm{M} 74 \mathrm{H}^{\alpha}, \mathrm{F} 73 \mathrm{H}^{\alpha}$, and $\mathrm{E} 72 \mathrm{H}^{\alpha}$, and these overlapping peaks are resolved in the $4 \mathrm{D}{ }^{13} \mathrm{C},{ }^{15} \mathrm{~N}$-edited NOESY-HSQC experiment (data not shown). Likewise, $\mathrm{H}^{\alpha} \mathrm{H}^{\beta}(i, i+3)$ NOEs were difficult to assign unambiguously in the $3 \mathrm{D}{ }^{13} \mathrm{C}$-edited NOESY-HSQC, but they could be routinely assigned in the $4 \mathrm{D}{ }^{13} \mathrm{C},{ }^{13} \mathrm{C}$-edited NOESY$\mathrm{HMQC}$ as illustrated for correlations from $\mathrm{V} 80 \mathrm{H}^{\alpha}$ to $\mathrm{A} 83 \mathrm{H}^{\beta}$ and for $\mathrm{A} 83 \mathrm{H}^{\alpha}$ to $\mathrm{E} 86 \mathrm{H}^{\beta}$ (Fig. 3). In summary, it was possible to unambiguously assign about $50 \%$ of the NOEs using 3D alone, whereas $>98 \%$ of the resonances could be assigned with a combination of 3D and 4D NMR data.

\section{Secondary structure and changes in the $C$-terminus of $\mathrm{Ca}^{2+}$-loaded $\operatorname{S100B}(\beta \beta)$ upon peptide binding}

A diagram illustrating NOE correlations, chemical shift index, amide exchange rates, and scalar coupling constants $\left({ }^{3} \mathrm{~J}_{\mathrm{NH}-\mathrm{H} \alpha}\right)$ used for characterizing the secondary structure of $\mathrm{Ca}^{2+}$-loaded $\mathrm{S} 100 \mathrm{~B}(\beta \beta)$ bound to the p53 peptide is shown in Figure 4 (Wuthrich, 1986; Spera \& Bax, 1991; Wishart et al., 1992; Wishart \& Sykes, 1994). When the p53 peptide is bound, each $\mathrm{S} 100 \beta$ subunit has four helices (helix 1, Glu2-Arg20; helix 2, Lys29-Asn38; helix 3, Gln50Asp61; helix 4, Phe70-Phe87), four loops (loop 1, Glu21-His25; loop 2, Glu39-Glu49; loop 3, Glu62-Gly66; loop 4, Phe88-Glu91), and two $\beta$-strands ( $\beta$-strand 1, Lys26-Lys $28 ; \beta$-strand 2, Glu67Asp69), which together form a short antiparallel $\beta$-sheet.

\section{$\beta$-Sheet}

As with apo- and $\mathrm{Ca}^{2+}$-bound $\operatorname{S100B}(\beta \beta)$, the two $\beta$-strands are antiparallel and bring the $\mathrm{Ca}^{2+}$-binding domains of $\mathrm{S} 100 \mathrm{~B}(\beta \beta)$ in the presence of the $\mathrm{p} 53$ peptide into close proximity. Residues in the two $\beta$-strands display the characteristic strong $\mathrm{H}^{\alpha} \mathrm{H}^{\mathrm{N}}(i, i+1)$ NOE correlations, upfield-shifted ${ }^{13} \mathrm{C}^{\alpha}$ and downfield-shifted ${ }^{1} \mathrm{H}^{\alpha}$ resonances. Furthermore, the measured ${ }^{3} J_{\mathrm{NH}-\mathrm{H} \alpha}$ coupling constants of these residues have the largest values $(6.6-9.1 \mathrm{~Hz})$, and their amide proton exchange rates are among the slowest indicative of hydrogen bonding or solvent inaccessibility. In addition, longrange NOE correlations between the two $\beta$-strands are observed in $3 \mathrm{D}{ }^{15} \mathrm{~N}$-edited NOESY-HSQC, 3D ${ }^{15} \mathrm{~N},{ }^{15} \mathrm{~N}$-edited HMQC-NOESYHSQC, 4D ${ }^{13} \mathrm{C},{ }^{15} \mathrm{~N}$-edited NOESY-HSQC experiments and confirm the antiparallel alignment of these two $\beta$-strands (data not shown).

\section{$\alpha$-Helices}

Characteristic NOE correlations, downfield-shifted ${ }^{13} \mathrm{C}^{\alpha}$ and upfield-shifted ${ }^{1} \mathrm{H}^{\alpha}$ resonances, small ${ }^{3} J_{\mathrm{NH}-\mathrm{H} \alpha}$ coupling constants $(<5 \mathrm{~Hz})$, and the slow amide proton exchange rates $(>18 \mathrm{~h})$ typical of $\alpha$-helices are observed in each of the four helices. Interestingly, helix 4 is longer by four to five residues (A83-F87) in the peptide complex as compared to helix 4 in $\mathrm{Ca}^{2+}$-bound rat $\operatorname{S100B}(\beta \beta)$ (Drohat et al., 1998). While there is a possibility that these residues (A83-F87) have a tendency to form a nascent helix 


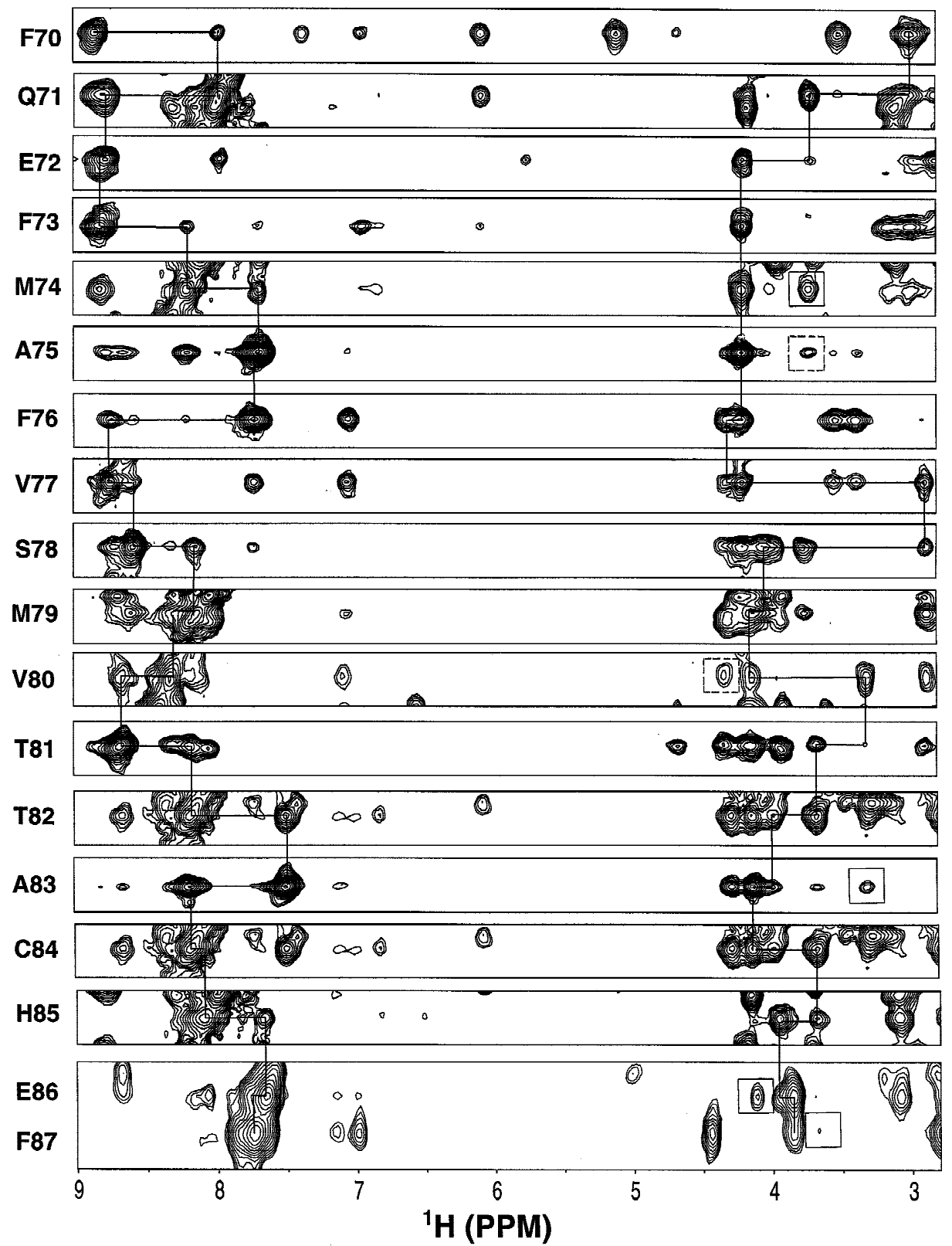

Fig. 1. Strips extracted from the ${ }^{15} \mathrm{~N}$ planes of a $3 \mathrm{D}{ }^{15} \mathrm{~N}$-edited NOESY-HSQC spectrum to illustrate NOE correlations in helix 4 (residue F70 to F87). Strip plots of 3D ${ }^{15} \mathrm{~N}$-edited NOESY-HSQC spectra of $\mathrm{Ca}^{2+}$-loaded S100B $(\beta \beta)$ bound to p53 peptide for helix 4. Lines trace the connectivities of sequential strong $\mathrm{H}^{\mathrm{N}} \mathrm{H}^{\mathrm{N}}(i, i+1)$ and weak $\mathrm{H}^{\alpha} \mathrm{H}^{\mathrm{N}}(i, i+1)$, while the $\mathrm{H}^{\beta} \mathrm{H}^{\mathrm{N}}(i, i+1)$ correlations have been omitted for clarity. Whenever visible, the $\mathrm{H}^{\alpha} \mathrm{H}^{\mathrm{N}}(i, i+3)$ and $\mathrm{H}^{\alpha} \mathrm{H}^{\mathrm{N}}(i, i+4)$ connectivities are depicted by enclosed solid and dashed boxes, respectively.

in the $\mathrm{Ca}^{2+}$-bound state based on chemical shift indexes (Drohat et al., 1998), NOE correlations typical of stable helix formation were not detected. This could perhaps be due to conformational exchange on the chemical shift time scale that is observed for residues T81 to F87 (Fig. 5A). Figure 5B illustrates that any exchange broadening effects in helix 4 are virtually eliminated upon the addition of the $\mathrm{p} 53$ peptide to $\mathrm{Ca}^{2+}$-bound $\mathrm{S} 100 \mathrm{~B}(\beta \beta)$. The narrowing of the HSQC correlations for residues in the $\mathrm{C}$-terminus of helix 4 upon peptide binding is accompanied by the appearance of strong NOE correlations consistent with their inclusion in helix 4 (Fig. 4). Thus, helix 4 is extended to include residues A83-
F87, and there are no longer any intermediate or slow conformational exchange processes for residues of helix 4 in the peptide complex (Fig. 5).

The extension at helix 4 to include A83-F87 can also occur for $\mathrm{Ca}^{2+}$-loaded human $\mathrm{S} 100 \mathrm{~B}(\beta \beta)$ in the absence of target protein (Smith \& Shaw, 1997); however, the lack of exchange broadening for the C-terminal residues of helix 4 in this study is likely induced by the $10 \%$ TFE included in the NMR samples. Furthermore, the crystal structure of $\mathrm{Ca}^{2+}$-bound bovine $\mathrm{S} 100 \mathrm{~B}(\beta \beta)$ shows a longer helix 4 than that of $\mathrm{Ca}^{2+}$-bound rat $\operatorname{S100B}(\beta \beta)$ (Matsumura et al., 1998), but this difference in structure could be the result of inter- 


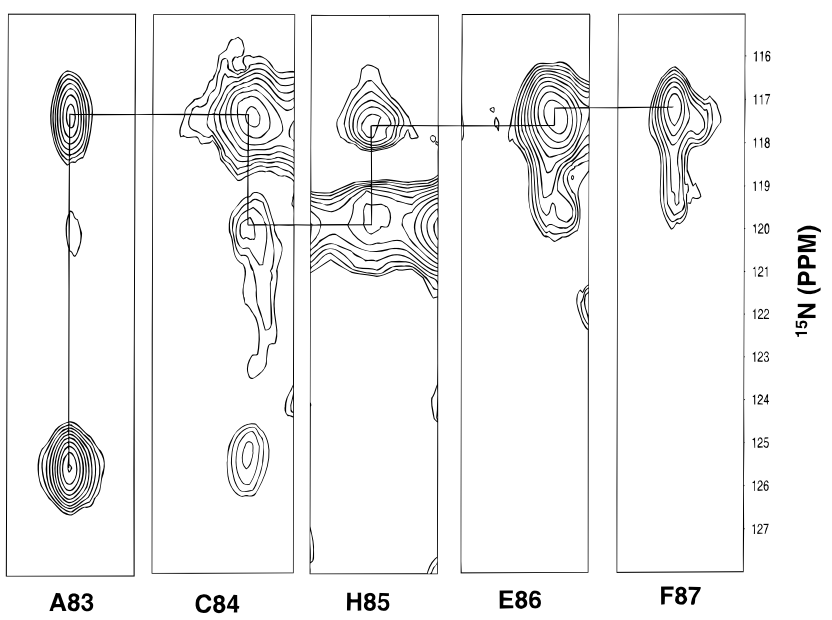

Fig. 2. Strips extracted from the ${ }^{15} \mathrm{~N}$ planes of a $3 \mathrm{D}{ }^{15} \mathrm{~N},{ }^{15} \mathrm{~N}$-edited HMQCNOESY-HSQC spectrum to illustrate NOE correlations in the extension of helix 4 (residue A83 to F87). Strip plots of 3D ${ }^{15} \mathrm{~N}$, ${ }^{15} \mathrm{~N}$-edited HMQCNOESY-HSQC spectra of $\mathrm{Ca}^{2+}$-loaded $\mathrm{S} 100 \mathrm{~B}(\beta \beta)$ bound to $\mathrm{p} 53$ peptide illustrating the $\mathrm{H}^{\mathrm{N}}-\mathrm{H}^{\mathrm{N}}$ connectivities for residues A83 through F87. The lines trace the connectivities of sequential strong $\mathrm{H}^{\mathrm{N}} \mathrm{H}^{\mathrm{N}}(i, i+1)$ correlations. molecular crystal lattice packing, which could stabilize the longer helix in the crystalline state. Our data support the notion that the C-terminus of $\mathrm{Ca}^{2+}$-loaded $\operatorname{S100B}(\beta \beta)$ is in a slow conformational averaging regime in a totally aqueous environment. In solution, these residues (A83-F87) form a stable helix upon target protein binding or by the addition of organic solvents such as TFE; crystallization can also stabilize the extra turn of helix in the absence of a bound protein target.

\section{Amide exchange}

The exchange rates of many amide protons of $\mathrm{Ca}^{2+}$-loaded $\operatorname{S100B}(\beta \beta)$ bound to 553 peptide are slower than in the absence of bound peptide (Fig. 4). In particular, the amide proton of residues in helix 1 (L10), helix 2 (K33 and N37), the hinge region (F43 and I47), helix 3 (K55, V56, E58, T59, L60, and D61), loop 3 (G66), and helix 4 (Q71, T82, A83, and C84) are present after $0.25 \mathrm{~h}$ in $\mathrm{D}_{2} \mathrm{O}$ for $\mathrm{S} 100 \mathrm{~B}(\beta \beta)$ bound to the $\mathrm{p} 53$ peptide, but they are absent after $0.25 \mathrm{~h}$ in the peptides absence (Drohat et al., 1998). Interestingly, 12 out of the 16 residues that showed a distinct slowing in amide exchange rates occur for amide protons in helix 3 , the hinge, and helix 4 . The fact that these same regions of $\mathrm{S} 100 \mathrm{~B}(\beta \beta)$
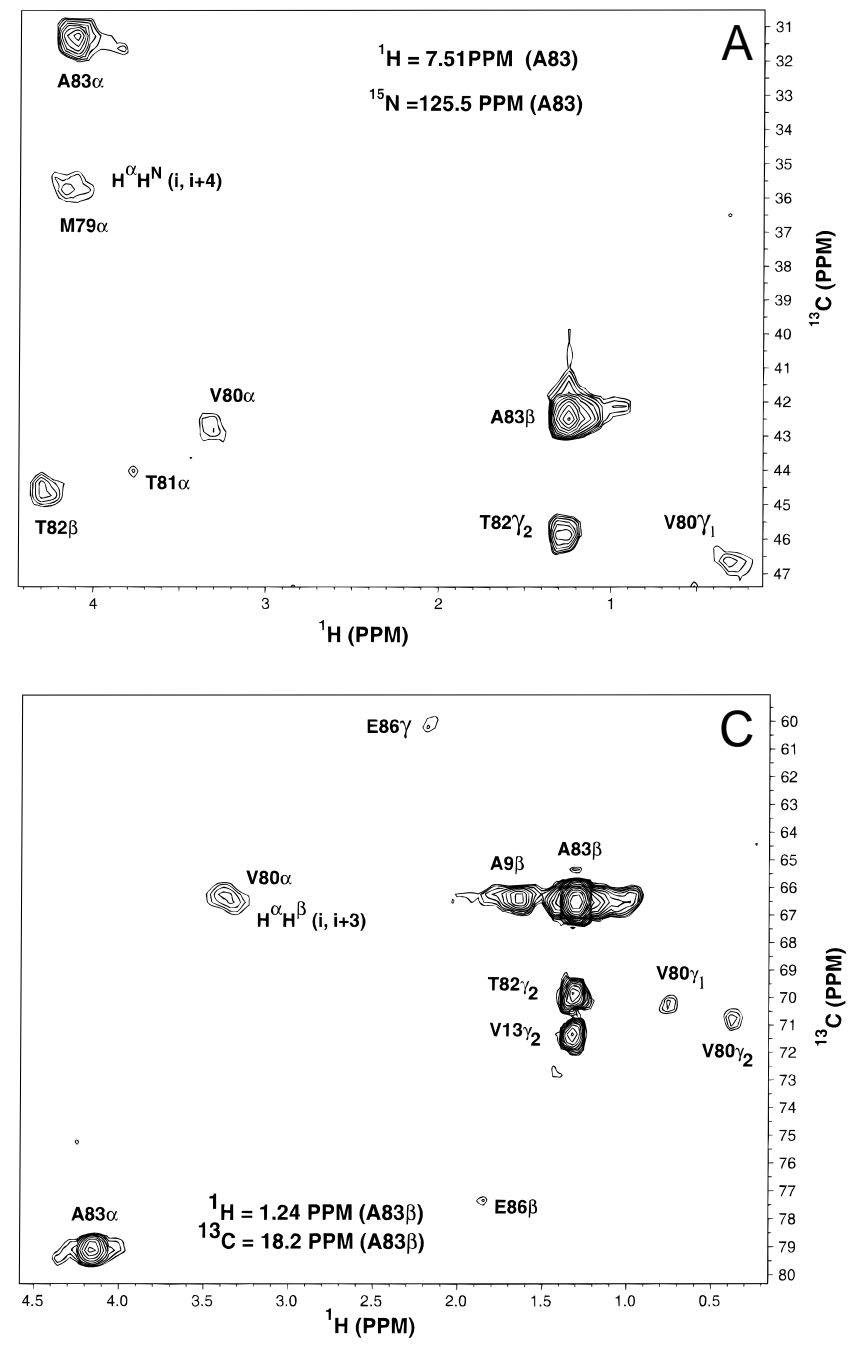

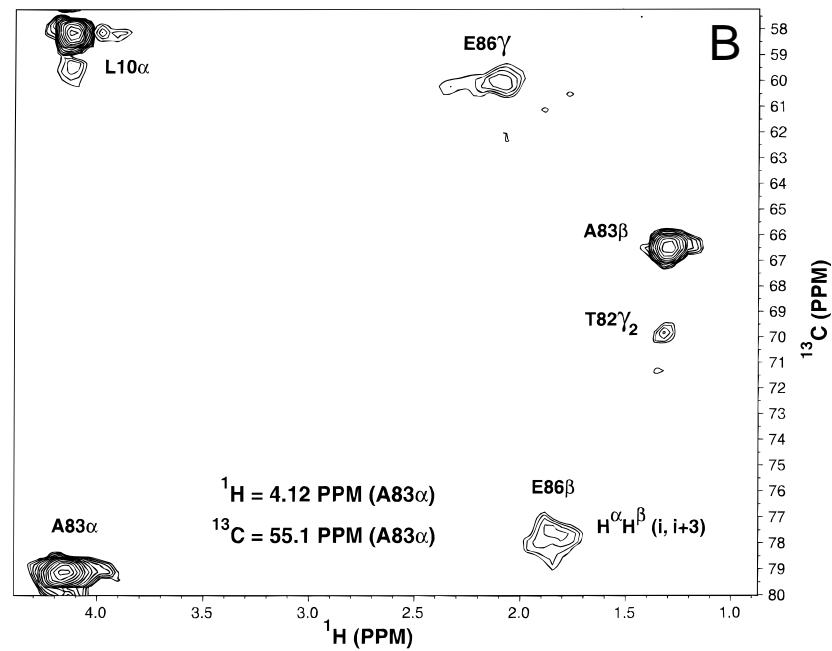

Fig. 3. NOE spectra illustrating sequential and medium-range NOE correlations. A: A plane from the $4 \mathrm{D}^{13} \mathrm{C},{ }^{15} \mathrm{~N}$-edited NOESY-HSQC spectrum shows NOE correlations of $\mathrm{H}^{\beta} \mathrm{H}^{\mathrm{N}}(i, i+1), \mathrm{H}^{\alpha} \mathrm{H}^{\mathrm{N}}(i, i+2), \mathrm{H}^{\alpha} \mathrm{H}^{\mathrm{N}}(i, i+3)$, $\mathrm{H}^{\alpha} \mathrm{H}^{\mathrm{N}}(i, i+4)$. In particular, NOE correlation of $\mathrm{H}^{\alpha} \mathrm{H}^{\mathrm{N}}(i, i+4)$ is clearly observed. This is ambiguous in $3 \mathrm{D}^{15} \mathrm{~N}$-edited NOESY-HSQC due to chemical shift degeneracy of $\mathrm{A} 83 \mathrm{H}^{\alpha}$ and $\mathrm{M} 79 \mathrm{H}^{\alpha}$. B: A plane from $4 \mathrm{D}{ }^{13} \mathrm{C}$, ${ }^{13} \mathrm{C}$-edited NOESY spectrum shows the medium NOE correlations of $\mathrm{H}^{\alpha} \mathrm{H}^{\beta}(i, i+3)$ between $\mathrm{A} 83 \mathrm{H}^{\alpha}$ and $\mathrm{E} 86 \mathrm{H}^{\beta}$. C: Similarly, A plane from $4 \mathrm{D}$ ${ }^{13} \mathrm{C},{ }^{13} \mathrm{C}$-edited NOESY spectrum shows the medium NOE correlations of $\mathrm{H}^{\alpha} \mathrm{H}^{\beta}(i, i+3)$ between $\mathrm{V} 80 \mathrm{H}^{\alpha}$ and $\mathrm{A} 83 \mathrm{H}^{\beta}$. Note that several peaks are folded in the ${ }^{13} \mathrm{C}$ dimension; the actual chemical shift values for the folded peaks can be calculated using a sweep width of $24 \mathrm{ppm}$. 


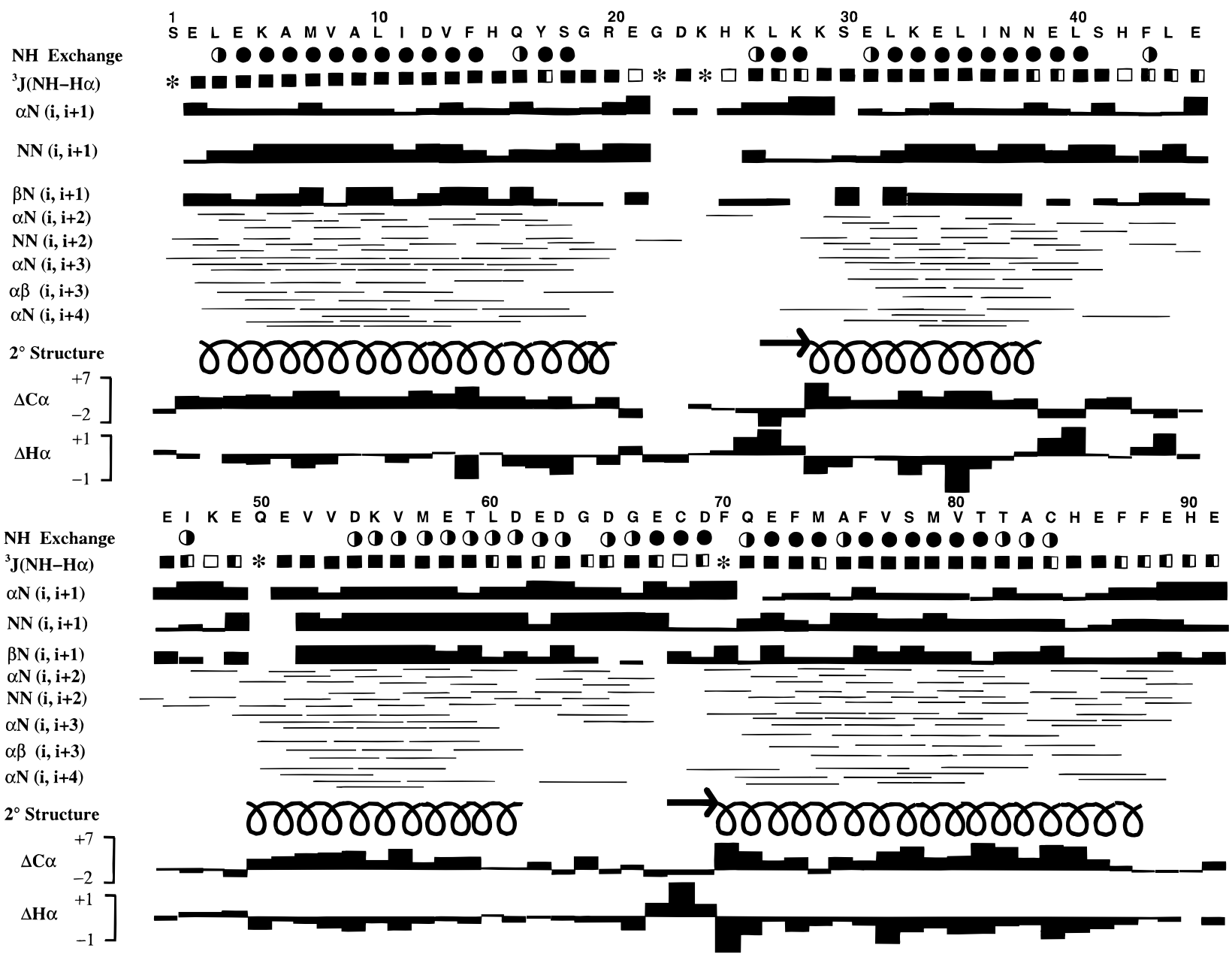

Fig. 4. Diagram of NMR data used to determine the secondary structure of $\mathrm{Ca}^{2+}$-loaded $\mathrm{S} 100 \mathrm{~B}(\beta \beta)$ bound to p53 peptide. The amide proton exchange rates are categorized as fast $(T<0.25 \mathrm{~h})$, medium $(0.25 \mathrm{~h}<T<18 \mathrm{~h})$, and slow $(T>18 \mathrm{~h})$ with no circle, half-shaded, and solid, respectively. The ${ }^{3} J_{\mathrm{NH}-\mathrm{H} \alpha}$ couplings are labeled as small $(J<5 \mathrm{~Hz})$, medium $(5<J<8 \mathrm{~Hz})$, and large $(J>$ $8 \mathrm{~Hz}$ ) with solid, half-shaded, and no square, respectively. The asterisks denote residues which lack $\mathrm{H}^{\alpha}$ or $\mathrm{H}^{\mathrm{N}}$ cross peaks in the HNHA and/or in HSQC. The sequential and medium NOE correlations are represented by bar height indicating the strength of the NOE (strong, medium, weak, and very weak) and by horizontal lines connecting the two participating residues, respectively. The deviation in the ${ }^{13} \mathrm{C}^{\alpha}$ and ${ }^{1} \mathrm{H}^{\alpha}$ chemical shifts from those of a random coil are indicated by the positive and negative bars as described (Spera \& Bax, 1991; Wishart \& Sykes, 1994). The overall secondary structure of $\mathrm{Ca}^{2+}$-loaded $\mathrm{S} 100 \mathrm{~B}(\beta \beta)$ bound to p53 peptide is depicted as spirals for helices and arrows for $\beta$-strands.

give rise to large chemical shift perturbations and intermolecular NOE correlations (Table 1) to the p53 peptide upon binding (Rustandi et al., 1998b) further supports the notion that residues in this region of the protein comprise a site that interacts with the $\mathrm{p} 53$ peptide.

\section{Model for target protein binding}

A large conformational change in $\operatorname{S100B}(\beta \beta)$, in which helix 3 reorients by $\sim 90^{\circ}$, is required for its binding to protein targets such as a peptide derived from the negative regulatory domain of $\mathrm{p} 53$ (Drohat et al., 1998, 1999). This conformational change exposes several residues in the hinge region, helix 3 , helix 4 , and the C-terminal loop of $\operatorname{S100B}(\beta \beta)$. Residues in these regions of $\operatorname{S} 100 \mathrm{~B}(\beta \beta)$ likely define the target protein binding site since the addition of the p53 peptide causes chemical shift perturbations
(Rustandi et al., 1998b), slows amide exchange rates (Fig. 4), extends helix 4 by one turn, and give rise to intermolecular NOE correlations between the peptide and $\operatorname{S100B}(\beta \beta)$ (Table 1; Figs. 6, 7).

On the other hand, these data are not consistent with a model for target protein binding put forward by Matsumura et al. (1998). Matsumura's model predicts that a single target protein binds per S100B dimer, and that it interacts solely with residues in helices 4 and $4^{\prime}$ at the dimer interface. This original model for binding is unlikely because thermodynamic titrations indicate that one p53 peptide binds each $\mathrm{S} 100 \beta$ subunit (Rustandi et al., 1998b). In addition, the Matsumura model does not adequately explain the slower amide exchange rates for residues in helix 3, many of the chemical shift perturbations observed previously (Rustandi et al., 1998b), or several of the intermolecular NOE correlations between the p53 peptide and $\operatorname{S100B}(\beta \beta)$ (Table 1; Fig. 7). For example, while the intermolecular NOE correlations from helix 1 (L3 and M7) and 

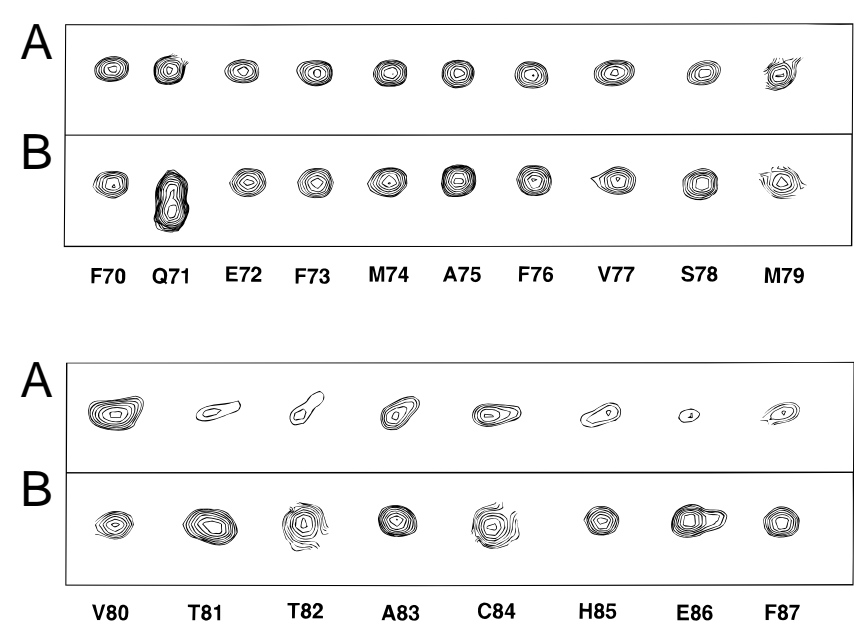

Fig. 5. A comparison of HSQC peaks between (A) $\mathrm{Ca}^{2+}$-loaded $\mathrm{S} 100 \mathrm{~B}(\beta \beta)$ and $(\mathbf{B}) \mathrm{Ca}^{2+}$-loaded $\mathrm{S} 100 \mathrm{~B}(\beta \beta)$ bound to the $\mathrm{p} 53$ peptide. The experiments were performed under identical conditions. Note that peaks of residue T81 through $\mathrm{F} 87$ in $\mathrm{Ca}^{2+}$-bound $\operatorname{S100B}(\beta \beta)$ are much weaker due to intermediate and/or slow conformational exchange broadening when compared to $\mathrm{Ca}^{2+}$-loaded $\mathrm{S} 100 \mathrm{~B}(\beta \beta)$ bound to the $\mathrm{p} 53$ peptide.

helix 4 (M74, V77, M79, V80, T82, and A83) could be explained by the Matsumura model, the intermolecular NOE correlations from loop 2 (L44, I47, K48), helix 2 (L35, I36), and helix 3 (E51, V52, V53, K55, V56, M57) can only be explained by a model for the target protein binding that also includes residues in helix 2, helix 3 , and loop 2. Since these residues are distant from the dimer interface, a revised model is required that includes all of the res-

Table 1. Intermolecular $N O E$ from $\operatorname{S1OOB}(\beta \beta)$ residues to the p53 peptide in the $\operatorname{S100B}(\beta \beta)-\mathrm{Ca}^{2+}{ }_{-}$p53 peptide complex

\begin{tabular}{|c|c|c|}
\hline $\begin{array}{l}\text { Residue in } \\
\operatorname{S} 100 \mathrm{~B}(\beta \beta)\end{array}$ & $\begin{array}{c}\delta \\
(\mathrm{ppm})\end{array}$ & $\begin{array}{l}\text { Protons } \delta(\mathrm{ppm}) \text { observed } \\
\text { in p53 peptide }\end{array}$ \\
\hline $\mathrm{L} 3 \delta$ & 1.11 & $0.95,0.85$ \\
\hline M7 $\epsilon$ & 1.77 & $0.86,0.77$ \\
\hline $\mathrm{L} 35 \delta$ & 0.75 & $1.00,0.59$ \\
\hline $\mathrm{I} 36 \gamma_{2}$ & 1.04 & $0.92,0.77$ \\
\hline $\mathrm{L} 44 \delta$ & 0.77 & $1.83,1.68,1.61,1.31$ \\
\hline $\mathrm{I} 47 \delta$ & 0.71 & $1.01,0.59$ \\
\hline $\mathrm{K} 48 \gamma$ & 1.34 & 1.71 \\
\hline 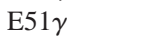 & 2.34 & 2.08 \\
\hline V $52 \gamma_{2}$ & 1.08 & $1.12,0.86,0.82$ \\
\hline V53 $\gamma_{1}$ & 0.91 & $3.20,1.65,0.77$ \\
\hline $\mathrm{V} 53 \gamma_{2}$ & 0.91 & $1.12,0.77$ \\
\hline $\mathrm{K} 55 \gamma$ & 1.53 & $2.05,1.97,1.70,1.12$ \\
\hline $\mathrm{V} 56 \gamma_{1}$ & 0.52 & $2.27,1.64,0.90,0.77$ \\
\hline M57 $\epsilon$ & 1.91 & 2.26 \\
\hline $\mathrm{M} 74 \epsilon$ & 1.64 & 0.86 \\
\hline $\mathrm{V} 77 \gamma_{1}$ & 0.26 & $1.64,0.86$ \\
\hline M79 $\epsilon$ & 2.11 & $3.16,2.60,2.46,1.63,0.86,0.77$ \\
\hline $\mathrm{V} 80 \gamma_{1}$ & 0.34 & $1.63,0.92,0.88,0.77$ \\
\hline $\mathrm{V} 80 \gamma_{2}$ & 0.70 & $0.90,0.77$ \\
\hline $\mathrm{T} 82 \gamma_{2}$ & 1.32 & $2.47,2.43,1.63,1.41,0.77$ \\
\hline $\mathrm{A} 83 \beta$ & 1.24 & $1.60,0.86,0.77$ \\
\hline
\end{tabular}

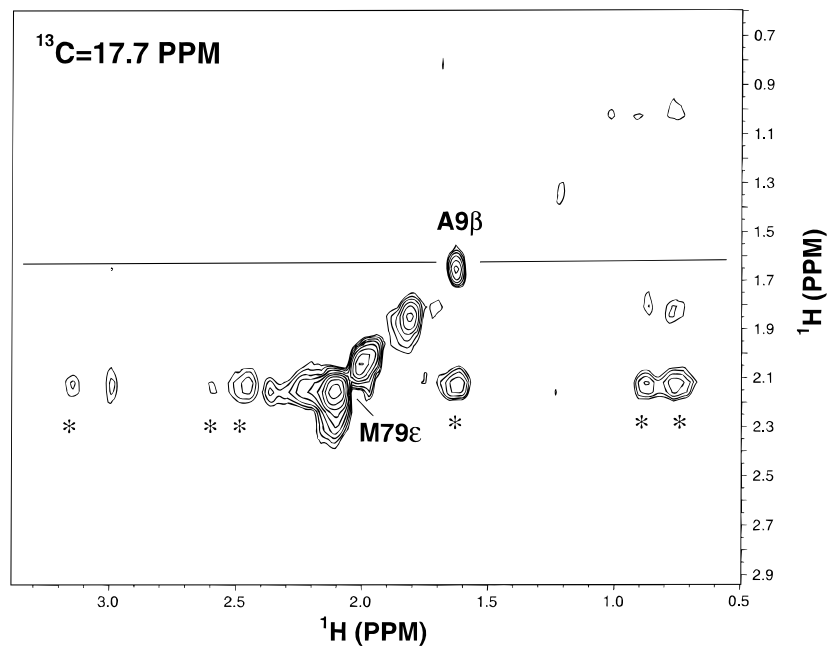

Fig. 6. Plane of the 3D isotope filtered NOESY spectra illustrating intermolecular NOE correlations (labeled with asterisks) between M79 (of $\operatorname{S100B}(\beta \beta)$ and several resonances of the p53 peptide. This plane also contains the methyl group of A9, which is not in proximity to the peptide based on its lack of intermolecular NOE correlations.

idues that give rise to intermolecular NOE correlations (Table 1; Fig. 7). As expected, this group of residues forms a surface that is distinctly present on each $\mathrm{S} 100 \beta$ subunit of dimeric $\operatorname{S100B}(\beta \beta)$, which is consistent with the thermodynamic binding studies.

A general role for the hinge and the C-terminal loop in the binding of $S 100$ protein targets

It has been known for a long time that the hinge region (loop 2) and the C-terminal loop are the least conserved regions of the S100 protein family (Kligman \& Hilt, 1988). A number of studies are reported that demonstrate a role for these regions in various S100target protein complexes. For example, a peptide based on the

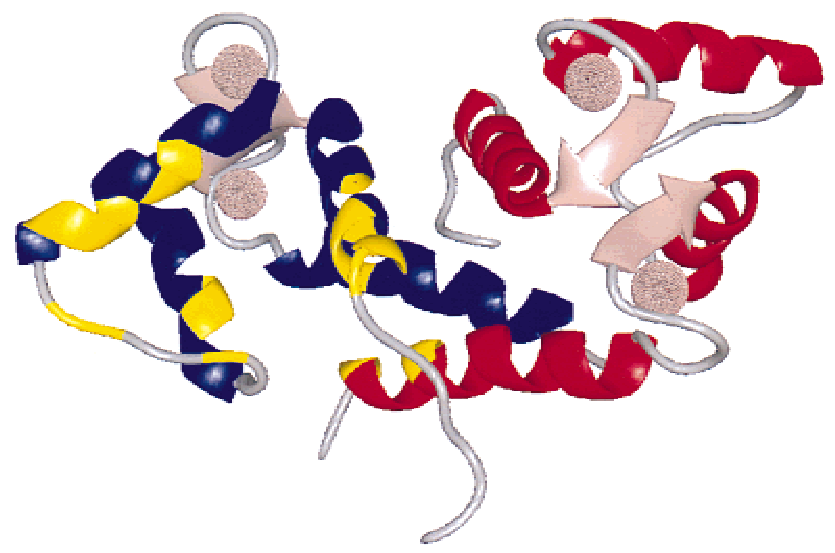

Fig. 7. Ribbon diagram of $\mathrm{Ca}^{2+}$-bound $\mathrm{S} 100 \mathrm{~B}(\beta \beta)$. Residues in one of the two symmetrical subunits of $\mathrm{S} 100 \mathrm{~B}(\beta \beta)$ that show intermolecular NOE correlations to the p53 peptide (Table 1) are shown in yellow. While the same intermolecular NOE correlations exist for residues in the other target protein binding site of dimeric $\mathrm{S} 100 \mathrm{~B}(\beta \beta)$, these residues are not highlighted in yellow. 
hinge region of $\mathrm{CP}-10$ was found to exhibit chemotactic activity similar to that of full-length protein (Lackmann et al., 1993), mutation of residues in the C-terminus of p11 was found to abolish annexin I binding (Kube et al., 1992), chemical modification and mutagenesis of $\mathrm{C} 84$ in $\mathrm{S} 100 \mathrm{~B}(\beta \beta)$ were found to decrease binding to $\tau$-protein (Baudier \& Cole, 1988) and aldolase (Landar et al., 1997), a peptide derived from the hinge region (L32-L40) of $\operatorname{S100B}(\beta \beta)$ has been shown to block the $\operatorname{S100B}(\beta \beta)$ activation of guanylate cyclase and inhibition of $\mathrm{p} 80$ phosphorylation, while a peptide derived from the $\mathrm{C}$-terminal region of $\mathrm{S} 100 \mathrm{~B}(\beta \beta)$ blocks guanylate cyclase and stimulates $\operatorname{S100B}(\beta \beta)$ in inhibiting $\mathrm{p} 80$ phosphorylation (Pozdnyakov et al., 1998). Recently, binding studies of point and deletion mutants of another S100 protein, S100A1, to phenyl-Sepharose and CapZ peptide indicate that S100A1 lacking several C-terminal residues (C85-S93) fails to bind phenylSepharose and exhibits a significantly reduced $\mathrm{Ca}^{2+}$-dependent interaction with the CapZ peptide (Landar et al., 1998). Furthermore, another truncated S100A1 protein lacking several residues in the C-terminus (F88-S93) is not able to inhibit GFAP assembly; also, this truncated S100A1 mutant is less able to complex with GFAP and does not complex to tubulin (Garbuglia et al., 1999). Thus, our conclusion regarding the $\mathrm{Ca}^{2+}$-dependent interaction of the p53 peptide with residues in the hinge and C-terminus of $\mathrm{S} 100 \mathrm{~B}(\beta \beta)$ is consistent with previous studies of $\mathrm{S} 100 \mathrm{~B}$ and other S100 proteins.

\section{Materials and methods}

\section{Materials}

All chemical reagents were ACS grade or higher and purchased from Sigma (St. Louis, Missouri) unless otherwise indicated. All buffers were passed through Chelex-100 resin (Bio-Rad, Hercules, California) to remove trace metals. Perdeuterated Tris, $d_{11}$-Tris ( $1 \mathrm{M}$ solution in $\mathrm{D}_{2} \mathrm{O},>98.7$ atom percent deuterium) was purchased from C/D/N Isotopes, Inc. (Vandreuil, Quebec), $\mathrm{D}_{2} \mathrm{O}$ (100.0 atom percent deuterium, low in paramagnetic impurities) was purchased from Aldrich Chemical Company (Milwaukee, Wisconsin). ${ }^{15} \mathrm{NH}_{4} \mathrm{Cl}(>99 \%)$ and ${ }^{13} \mathrm{C}$-labeled glucose were purchased from Cambridge Isotope Laboratories (Woburn, Massachusetts).

\section{Preparation of $\operatorname{S100B}(\beta \beta)$ and p53-derived peptide}

Recombinant $\mathrm{S} 100 \mathrm{~B}(\beta \beta)$ was prepared as previously described (Amburgey et al., 1995). Briefly, rat $\operatorname{S100B}(\beta \beta)$ was overexpressed in Escherichia coli strain HMS174(DE3) transformed with an expression plasmid containing a cDNA encoding $\operatorname{S100B}(\beta \beta)$ gene. Unlabeled, ${ }^{15} \mathrm{~N}$-labeled, and ${ }^{13} \mathrm{C},{ }^{15} \mathrm{~N}$-labeled $\mathrm{S} 100 \mathrm{~B}(\beta \beta)$ were purified $(>99 \%)$ under reducing condition using procedures similar to those described previously (Amburgey et al., 1995; Drohat et al., 1996), except that $0.5 \mathrm{mM}$ DTT (Gibco BRL, Paisley, United Kingdom) was used as a reducing agent throughout the preparation instead of $\beta$-mercaptoethanol. The $\mathrm{S} 100 \beta$ subunit concentration was determined using the Bradford assay with a known $\operatorname{S100B}(\beta \beta)$ concentration sample as a standard. The concentration for the $\operatorname{S100B}(\beta \beta)$ standard used in the Bradford assay was determined by amino acid analysis (Analytical Biotechnology Services, Boston, Massachusetts).

A peptide, acetyl-SHLKSKKGQSTSRHKKLMFKTE-am, derived from human p53 (residues 367-388) was synthesized using solid-phase peptide synthesis (Biopolymer Laboratory, University of Maryland School of Medicine at Baltimore, Maryland) with its $\mathrm{N}$ - and C-termini acetylated (acetyl-) and amidated (-am), respectively. The p53 peptide was stored as a lyophilized powder and dissolved in $1 \mathrm{mM}$ Tris- $d_{11}-\mathrm{HCl}, \mathrm{pH} 7.6$ prior to use. The purity $(>99 \%)$ of the p53 peptide was determined using HPLC, and its concentration and composition were confirmed by amino acid analysis (Analytical Biotechnology Services). Subsequently, the p53 peptide concentration was determined spectrophotometrically using an extinction coefficient $\epsilon_{258}=427 \mathrm{~cm}^{-1} \mathrm{M}^{-1}$ at neutral $\mathrm{pH}$.

\section{NMR spectroscopy}

NMR samples contained 3.0-6.2 mM S100 $\beta$ (subunit concentration), $0.1 \mathrm{mM}$ EDTA, $0.34 \mathrm{mM} \mathrm{NaN}_{3}, 5 \mathrm{mM}$ DTT, $17 \mathrm{mM} \mathrm{NaCl}$, $10 \mathrm{mM} d_{11}$-Tris- $\mathrm{HCl}, 10 \% \mathrm{D}_{2} \mathrm{O}, 6.3-13 \mathrm{mM} \mathrm{CaCl}_{2}, \mathrm{pH}$ 6.5. The p53 peptide was lyophilized and redissolved as a stock solution $(60.5 \mathrm{mM})$ in $1 \mathrm{mM} d_{11}$-Tris-HCl. The $\mathrm{pH}$ of the stock solution was adjusted to 6.5 with cold dilute $\mathrm{HCl}$ prior to adding it to the NMR sample. The p53 peptide was titrated to a final concentration of 4.8-10 mM into $\mathrm{Ca}^{2+}$-loaded $\operatorname{S100B}(\beta \beta)$ samples.

All NMR spectra were acquired at $37^{\circ} \mathrm{C}$ with a Bruker (Karlsruhe, Germany) DMX600 NMR spectrometer $(600.13 \mathrm{MHz}$ for protons) equipped with four frequency channels and a triple resonance three-axis gradient probe. Unless otherwise stated, a $1 \mathrm{~s}$ relaxation delay was used, and quadrature detection in the indirect dimensions was obtained with States-TPPI phase cycling. For most experiments, initial delays in the indirect dimensions were set to give zero- and first-order phase corrections of $90^{\circ}$ and $-180^{\circ}$, respectively (Marion et al., 1989b; Bax et al., 1991). Data were processed on Silicon Graphics workstations using the processing program nmrPipe (Delaglio et al., 1995). Time-domain data in the indirect dimensions were extended by no more than one-third using standard linear prediction routines (Zhu \& Bax, 1992), except for data in constant time domains that were extended twofold using mirror-image linear prediction (Zhu \& Bax, 1990). All proton chemical shifts are reported with respect to the $\mathrm{H}_{2} \mathrm{O}$ or $\mathrm{HDO}$ signal taken as $4.658 \mathrm{ppm}$ relative to external TSP $(0.0 \mathrm{ppm})$ at $37^{\circ} \mathrm{C}$. The ${ }^{13} \mathrm{C}$ and ${ }^{15} \mathrm{~N}$ chemical shifts were indirectly referenced using the following ratios of the zero-point frequencies at $37^{\circ} \mathrm{C}$ : 0.10132905 for ${ }^{15} \mathrm{~N}$ to ${ }^{1} \mathrm{H}$ and 0.25144953 for ${ }^{13} \mathrm{C}$ to ${ }^{1} \mathrm{H}$ (Live et al., 1984; Spera \& Bax, 1991; Edison et al., 1994).

NMR experiments needed to assign the backbone chemical shifts of $\mathrm{Ca}^{2+}$-loaded $\mathrm{S} 100 \mathrm{~B}(\beta \beta)$ bound to $\mathrm{p} 53$ peptide have been described previously (Rustandi et al., 1998b). These include $2 \mathrm{D}{ }^{1} \mathrm{H}-{ }^{15} \mathrm{~N}$ fast HSQC (Mori et al., 1995), 3D ${ }^{15} \mathrm{~N}$-edited HOHAHA-HSQC (Bax \& Davis, 1985; Marion et al., 1989a; Cavanagh \& Rance, 1992), 3D HCCH-TOCSY (Kay et al., 1993), 3D CBCA(CO)NH (Grzesiek \& Bax, 1992; Muhandiram \& Kay, 1994), and 3D HNCACB (Wittekind \& Mueller, 1993). Additional 3D experiments include a 3D ${ }^{15} \mathrm{~N}$-edited NOESY-HSQC (Kay et al., 1989) collected using a $100 \mathrm{~ms}$ mixing time and an acquired data matrix of $512 * \times 106^{*} \times 28^{*}\left(*\right.$ indicates complex points). A $3 \mathrm{D}{ }^{15} \mathrm{~N}$, ${ }^{15} \mathrm{~N}$-edited HMQC-NOESY-HSQC (Ikura et al., 1990) experiment with a $512^{*} \times 21^{*} \times 21^{*}$ matrix was acquired with a $150 \mathrm{~ms}$ mixing time. A sensitivity-enhanced $4 \mathrm{D}{ }^{13} \mathrm{C},{ }^{15} \mathrm{~N}$-edited NOESY (Muhandiram et al., 1993) experiment was collected using a $100 \mathrm{~ms}$ mixing time and an acquired matrix of $256^{*} \times 13^{*} \times$ $64 * \times 19 *$ data points. A $4 \mathrm{D}{ }^{13} \mathrm{C},{ }^{13} \mathrm{C}$-edited NOESY (Vuister et al., 1993) spectrum was obtained with a $100 \mathrm{~ms}$ mixing time and a raw matrix of $256^{*} \times 64^{*} \times 18^{*} \times 18^{*}$ data points. Intermolec- 
ular NOE correlations from the peptide to $\operatorname{S100B}(\beta \beta)$ were recorded using 2D and 3D isotope filtered NOESY experiments (Vuister et al., 1994; Starich, 1995) with a $200 \mathrm{~ms}$ and $150 \mathrm{~ms}$ mixing time and data matrices of $512 * \times 316^{*}$ and $512^{*} \times 70^{*} \times$ $35^{*}$, respectively. The amide proton exchange experiments were done by lyophilizing the $\mathrm{S} 100 \mathrm{~B}(\beta \beta)-\mathrm{Ca}^{2+}$-p53 peptide complex from $\mathrm{H}_{2} \mathrm{O}$ and redissolving it in $\mathrm{D}_{2} \mathrm{O}$. Immediately following solvation, a series of fast ${ }^{1} \mathrm{H},{ }^{15} \mathrm{~N}$-HSQC experiments with intervals of $0.25,0.33,0.67,1.4,2.7,4.7,8.7,12.7,18.7,24.7 \mathrm{~h}$ were collected (Marion et al., 1989a). The measurements of ${ }^{3} J_{\mathrm{NH}-\mathrm{H} \alpha}$ coupling constants were obtained from the HNHA experiment as previously described (Vuister \& Bax, 1993; Kuboniwa et al., 1994). Uniformly ${ }^{15} \mathrm{~N}$-labeled $\operatorname{S} 100 \mathrm{~B}(\beta \beta)$ in the $\mathrm{S} 100 \mathrm{~B}(\beta \beta)-\mathrm{Ca}^{2+}-\mathrm{p} 53$ peptide was used to collect 3 D-HNHA spectrum with $512 * \times$ $60 * \times 80 *$ data points. The ${ }^{3} J_{\mathrm{NH}-\mathrm{H} \alpha}$ coupling constants were calculated from

$$
I_{\text {cross }} / I_{\text {diagonal }}=-\tan ^{2}(2 \pi J \xi)
$$

where $\xi=13.4 \mathrm{~ms}$ and $I_{\text {cross }} / I_{\text {diagonal }}$ is the intensity ratio of crosspeak to diagonal peak. The relaxation effects were taken into account as described in Vuister and Bax (1993).

\section{Supplementary material in Electronic Appendix}

Included in supplemental material is a table reporting the chemical shift values for $\mathrm{Ca}$-loaded $\mathrm{S} 100 \mathrm{~B}(\beta \beta)$ bound to the p53 peptide.

\section{Acknowledgments}

This work was supported by grants from the National Institutes of Health (Grant R01GM58888 to D.J.W.), the American Cancer Society (Grant JFRA641 to D.J.W.), the University of Maryland School of Medicine, and SRIS/ DRIF funding from the State of Maryland (to D.J.W.).

\section{References}

Amburgey JC, Abildgaard F, Starich MR, Shah S, Hilt DC, Weber DJ. 1995. ${ }^{1} \mathrm{H}$, ${ }^{13} \mathrm{C},{ }^{15} \mathrm{~N}$ NMR assignments and solution secondary structure of rat ApoS100ß. J Biomol NMR 6:171-179.

Baudier J, Cole RD. 1988. Interaction between the microtubule-associated $\tau$ proteins and $\mathrm{S} 100 \mathrm{~b}$ regulate $\tau$ protein phosphorylation by the $\mathrm{Ca}^{+2} /$ calmodulin-dependent protein kinase II. J Biol Chem 263:5876-5883.

Bax A, Davis DG. 1985. MLEV-17-based two-dimensional homonuclear magnetization transfer spectroscopy. J Magn Reson 65:355-360.

Bax A, Ikura M, Kay LE, Zhu G. 1991. Removal of $F_{1}$ baseline distortion and optimization of folding in multidimensional NMR spectra. J Magn Reson 91:174-178.

Cavanagh J, Rance M. 1992. Suppression of cross-relaxation effects in TOCSY spectra via a modified DIPSI-2 mixing sequence. J Magn Reson 96:670678.

Delaglio F, Grzesiek S, Vuister GW, Zhu G, Pfeifer J, Bax A. 1995. NMRPipe: A multidimensional spectral processing system based on UNIX pipes. $J$ Biomol NMR 6:277-293.

Drohat AC, Amburgey JC, Abildgaard F, Starich MR, Baldisseri D, Weber DJ. 1996. Solution structure of rat apo-S100B $(\beta \beta)$ as determined by NMR spectroscopy. Biochemistry 35:11577-11588.

Drohat AC, Baldisseri DM, Rustandi RR, Weber DJ. 1998. Solution structure of calcium-bound rat $\mathrm{S} 100 \mathrm{~B}(\beta \beta)$ as determined by nuclear magnetic resonance spectroscopy. Biochemistry 37:2729-2740.

Drohat AC, Nenortas E, Beckett D, Weber DJ. 1997. Oligomerization state of $\mathrm{S} 100 \mathrm{~B}(\beta \beta)$ at nanomolar concentration determined by large-zone analytical gel filtration chromatography. Protein Sci 6:1577-1582.

Drohat AC, Tjandra, N, Baldisseri, DM, Weber, DJ. 1999. The use of dipolar couplings for determining the solution structure of rat apo-S100B $(\beta \beta)$. Protein Sci 8:800-809.
Edison AS, Abildgaard F, Westler WM, Mooberry ES, Markley JL. 1994. Practical introduction to theory and implementation of multinuclear, multidimensional nuclear magnetic resonance experiments. Methods Enzymol 239:3-79.

Garbuglia M, Verzini M, Rustandi RR, Weber DJ, Osterloh D, Gerke V, Donato R. 1999. The C-terminal extension is essential for S100A1 to interact with GFAP, tubulin, and S100A1- and S100B-inhibitory peptide, TRTK-12, and a peptide derived from $\mathrm{p} 53$, and for S100A1 to inhibit GFAP polymerization. Biochem Biophys Res Commun. 254:36-41.

Grzesiek S, Bax A. 1992. Correlating backbone amide and side chain resonances in larger proteins by multiple relayed triple resonance NMR. J Am Chem Soc 114:6291-6293.

Ikura M, Bax A, Clore GM, Gronenborn AM. 1990. Detection of nuclear overhauser effects between degenerate amide proton resonances by heteronuclear three dimensional nuclear magnetic resonance spectroscopy. $J$ Am Chem Soc 112:9020-9022.

Kay LE, Marion D, Bax A. 1989. Practical aspects of 3D heteronuclear NMR of proteins. J Magn Reson 84:72-84.

Kay LE, Xu G-Y, Singer AU, Muhandiram DR, Forman-Kay JD. 1993. A gradient-enhanced $\mathrm{HCCH}$-TOCSY experiment for recording side-chain ${ }^{1} \mathrm{H}$ and ${ }^{13} \mathrm{C}$ correlations in $\mathrm{H}_{2} \mathrm{O}$ samples of proteins. J Magn Reson B101: 333-337.

Kilby PM, Van Eldik LJ, Roberts GCK. 1996. The solution structure of the bovine S100B protein dimer in the calcium-free state. Structure 4:10411052.

Kligman D, Hilt D. 1988. The S100 protein family. Trends Biochem Sci 13:437443.

Kube E, Becker T, Weber K, Gerke V. 1992. Protein-protein interaction studied by site-directed mutagenesis. J Biol Chem 267:14175-14182.

Kuboniwa H, Grzesiek S, Delaglio F, Bax A. 1994. Measurement of $\mathrm{H}^{\mathrm{N}} \mathrm{H}^{\alpha} \mathrm{J}$ couplings in calcium-free calmodulin using new $2 \mathrm{D}$ and $3 \mathrm{D}$ water-flip-back methods. J Biomol NMR 4:871-878.

Lackmann M, Rajasekariah P, Iismaa SE, Jones G, Cornish CJ, Hu S, Simpson RJ, Moritz RL, Geczy CL. 1993. Identification of a chemotactic domain of the pro-inflammatory S100 protein CP-10. J Immunol 150:2981-2991.

Landar A, Hall TL, Cornwall EH, Correia JJ, Drohat AC, Weber DJ, Zimmer DB. 1997. The role of cysteine residues in S100B dimerization and regulation of target protein activity. Biochim Biophys Acta 1343:117-129.

Landar A, Rustandi RR, Weber DJ, Zimmer D. 1998. S100A1 utilizes different mechanism for interacting with calcium-dependent and calcium-independent target proteins. Biochemistry 37: 17429-17438.

Live DH, Davis DG, Agosta WC, Cowburn D. 1984. Long range hydrogen bond mediated effects in peptides: ${ }^{15} \mathrm{~N}$ NMR study of gramicidin $\mathrm{S}$ in water and organic solvents. J Am Chem Soc 106:1939-1941.

Marion D, Driscoll PC, Kay CM, Wingfield PT, Bax A, Gronenborn AM, Clore GM. 1989a. Overcoming the overlap problem in the assignment of ${ }^{1} \mathrm{H}$ NMR spectra of larger proteins using three-dimensional homonuclear HartmanHahn and nuclear Overhauser ${ }^{1} \mathrm{H}^{-15} \mathrm{~N}$ heteronuclear multiple quantum coherence spectroscopy. Biochemistry 28:6150-6156.

Marion D, Ikura M, Tschudin R, Bax A. 1989b. Rapid recording of 2D NMR spectra without phase cycling. J Magn Reson 85:393-399.

Matsumura H, Shiba T, Inoue T, Harada S, Kai Y. 1998. A novel mode of target recognition suggested by the $2.0 \AA$ structure of holo S100B from bovine brain. Structure 6:233-241.

Mori S, Abeygunawardana C, Johnson MO, Van Zijl PCM. 1995. Improved sensitivity of HSQC spectra of exchanging protons at short interscan delays using a new fast HSQC (FHSQC) detection scheme that avoids water saturation. J Magn Reson 108:94-98.

Muhandiram DR, Guang YX, Kay LE. 1993. An enhanced-sensitivity pure absorption gradient $4 \mathrm{D}{ }^{15} \mathrm{~N},{ }^{13} \mathrm{C}$-edited NOESY experiment. J Biomol NMR $3: 463-470$.

Muhandiram DR, Kay LE. 1994. Gradient-enhanced triple resonance threedimensional NMR experiments with improved sensitivity. J Magn Reson Ser B 102:203-216.

Pozdnyakov N, Margulis A, Sitaramayya A. 1998. Identification of effector binding sites on $\mathrm{S} 100 \beta$ : Studies with guanylate cyclase and $\mathrm{p} 80$, a retinal phosphoprotein. Biochemistry 37:10701-10708.

Rustandi RR, Baldisseri DM, Drohat AC, Weber DJ. 1998a. Secondary structure of $\mathrm{S} 100 \mathrm{~B}(\beta \beta)$ in $\mathrm{S} 100 \mathrm{~B}(\beta \beta)-\mathrm{Ca}^{2+}$-p53 peptide complex determined by NMR. FASEB J 12:1418.

Rustandi RR, Drohat AD, Baldisseri DM, Wilder PT, Weber DJ. 1998b. The $\mathrm{Ca}^{2+}$-dependent Interaction of $\mathrm{S} 100 \mathrm{~B}(\beta \beta)$ with a peptide derived from $\mathrm{p} 53$. Biochemistry 37:1951-1960.

Smith SP, Shaw GS. 1997. Assignment and secondary structure of calciumbound human S100B. J Biomol NMR 10:77-88.

Smith SP, Shaw GS. 1998. A novel calcium-sensitive switch revealed by the structure of human S100B in the calcium-bound form. Structure 6:211222. 
Spera S, Bax A. 1991. An empirical correlation between protein backbone conformation and $\mathrm{C}_{\alpha}$ and $\mathrm{C}_{\beta}$ chemical shifts. J Am Chem Soc 113:54905492

Starich MR. 1995. Three-dimensional solution structures of the HIV-1 matrix protein and the Hyperthermophilic histone, rHMfB, by heteronuclear multidimensional NMR [PhD Thesis]. Baltimore, Maryland: University of Maryland Baltimore County.

Vuister GW, Bax A. 1993. Quantitative J correlation: A new approach for measuring homonuclear three-bond $J\left(\mathrm{H}^{\mathrm{N}} \mathrm{H}^{\alpha}\right)$ coupling constants in ${ }^{15} \mathrm{~N}$ enriched proteins. J Am Chem Soc 115:7772-7777.

Vuister GW, Clore GM, Gronenborn AM, Powers R, Garrett DS, Tschudin R, Bax A. 1993. Increased resolution and improved spectral quality in fourdimensional ${ }^{13} \mathrm{C} /{ }^{13} \mathrm{C}$-separated HMQC-NOESY-HMQC spectra using pulsed field gradients. J Magn Reson B101:210-213.

Vuister GW, Kim S-J, Wu C, Bax A. 1994. 2D and 3D NMR study of phenylalanine residues in proteins by reverse isotopic labeling. J Am Soc 116:92069210
Wilder PT, Rustandi RR, Drohat AC, Weber DJ. 1998. S100B $(\beta \beta)$ inhibits the protein kinase $\mathrm{C}$-dependent phosphorylation of a peptide derived from $\mathrm{p} 53$ in a $\mathrm{Ca}^{2+}$-dependent manner. Protein Sci 7:794-798.

Wishart DS, Sykes BD. 1994. The 13C chemical-shift index: A simple method for the identification of protein seconary structure using $13 \mathrm{C}$ chemical-shift data. J Biomol NMR 4:171-180.

Wishart DS, Sykes BD, Richards FM. 1992. The chemical shift index: A fast and simple method for the assignment of protein secondary structure through NMR spectroscopy. Biochemistry 31:1647-1651.

Wittekind M, Mueller L. 1993. HNCACB, A high-sensitivity 3D NMR experiment to correlate amide-proton and nitrogen resonances with the alpha- and beta proton resonances in proteins. J Magn Reson B101:205-210.

Wuthrich K. 1986. NMR of proteins and nucleic acids. New York: John Wiley.

Zhu G, Bax A. 1990. Improved linear prediction for truncated signals of known phase. J Magn Reson 90:405-410.

Zhu G, Bax A. 1992. Two-dimensional linear prediction for signals truncated in both dimensions. J Magn Reson 98:192-199. 